\title{
SOVEREIGNTY OF A NATION IN THE PARLIAMENTARY SYSTEM OF LITHUANIA: PROBLEMS AND PROPOSALS
}

\author{
Saulius Arlauskas \\ Mykolas Romeris University, \\ Department of Philosophy of Law, \\ Ateities g. 20, LT-08303 Vilnius, Lithuania \\ E-mail: saularl@mruni.lt
}

\begin{abstract}
The aim of the article is to show in what way it is possible to guarantee the proper representation of human interests in the parliamentary form of government. To quote ideas of Mykolas Romeris concerning relationships between sovereign and State powers, it is stated that a special function of safeguarding of constitutionality as an expression of the Sovereign's will ought to be provided in the Constitution of Parliamentary Republic. In the article, it is demonstrated that such function is implemented in the Constitutions of France and Germany by granting a President to guarantee a proper work of parliamentary system (the function of political and legal reserve). It is also shown that in Lithuania, which is considered to be a Parliamentary Republic, the President does not perform a function of political and legal reserve and does not have appropriate authorizations. The author of the article proposes to follow the standards of Constitutions of France and Germany and to reconsider the competences between the institutions of the Seimas and the President.
\end{abstract}

Keywords: Constitution, Lithuania, sovereignty, State power separation.

doi:10.3846/limes.2010.11

\section{Introduction}

In the Constitution of Lithuania it is declared: "The nation founds the State of Lithuania. Sovereignty belongs to Nation". Further, the article 4 develops these provisions: "The nation exercises supreme power over its democratically elected representatives". Therefore, in the Constitution it is stated that the will of a nation is a source of authority powers. Only the nation is provided by the right to judge who and how one can govern the country.

On October 25, 1992, the people of Lithuania voted in the referendum for the enactment of new Constitution and believed that this organic law will safeguard proper work of the democratic institutions and protection of human interests. They did not doubt that the Seimas and the President that were elected in free and direct elections will well represent the will of the Sovereign - the Nation.

Although not so much time has passed, the trust of people in authorities significantly decreased. Many people do not believe that democratically elected State powers serve to justice and care for every Lithuanian human being. The gap between 
authorities and electors, in the opinion of Lithuanians, is constantly growing. The democracy representing institutions that are foreseen in the Constitution, let say, are operating but the distrust of people in them is growing. We can hear that the Sovereign in Lithuania - the Nation - in reality has lost its sovereignty and political elite while influential structures of business became the real Sovereign.

\section{The President as a guarantor of constitutionality in the parliamentary form of government}

\section{The competencies of State powers in the written Constitution as an expression of the will of the Sovereign}

While speaking about the increasing distrust of people in institutions of the political authorities it is very important to know on what legal ground the political institutions of authorities in the democratic State are obliged to represent the Sovereign - the Nation - and to protect Its interests. In this respect, it is important to clear up what is the relationship between the political government as a representative of the will of the Sovereign and of the Sovereign Itself. Namely, this question Romeris scrutinized in his work Sovereignty (Romeris 1995).

The aim of Romeris research is to answer the question of how political authority obtains the title to represent the State. The answer to this question is important in several aspects. Firstly, this answer has to show whether the Sovereign by providing the authorities with the powers to govern, at the same time provides the government institutions with the competence to act in the name of the Sovereign Itself? In other words, are the State powers institutions authorized to represent the will of the Sovereign directly? Secondly, it is important to clarify to what extent the citizens (nation) are obliged to submit to imperative decisions of political power and when citizens have the right to resist, if they consider that political authorities exercise the functions, which were entrusted by the Sovereign, not correctly?

Romeris states, that the nation while implementing the privilege of the State foundation power, places all its sovereignty as if in some magazine, written Constitution. "From the magazine - from Constitution deposited sovereign (nation's will) - different constitutionally founded organs of government, taking into account the definite of constitutional statutes, quasi through some culverts and taps, obtain the functional power to that extent to what the state foundation power founds necessary to state”, Romeris resumes (Romeris 1995: 179).

With these words, the author distinctly emphasizes that the Sovereign - the Nation implements its Sovereign power in the Constitution. The answer to both above formulated questions follows from this statement. Although the subjects of the political authorities are not the Sovereigns, through the functions determined in the Constitution they obtain the legal power (are empowered to exercise the functions of State authorities) to act in the name of the Sovereigns. At the same time, the electors being obliged to recognize the competence of authorities to act in the name of the Sovereign preserve the right to resist, if institutions of the political authorities infringe the limits of competence stated in the Constitution. 


\section{Institution of the President as direct representative of the will of the Sovereign to guarantee the constitutionality}

Romeris notes that after the implementation of the will of the Sovereign in the Constitution, the problem of constitutional construction (of constitutionality) safeguard becomes important. According to his opinion, there may always emerge groups that are determined "to grab the sovereignty magazined in the Constitution" (Romeris 1995: 196). The means for it not to happen is to compose "several tops of authorities' powers" (Romeris 1995: 203). The aim of this composition is to make it the way so that it is not one organ or person "in whose hands all Constitutional power would be concentrated" (Romeris 1995: 204).

At the same time Romeris notices another very important factor that would suit the good government of the State. According to him, while allocating functions of the State powers, it is important for eventual anarchy when "several tops of authorities will generate to the several governments" (Romeris 1995: 206) not to forget to happen. Then, the conflicts and mutual imputations between powers are inevitable. When there is no united government, there proper representation of electors' interests is lost.

Romeris did not propose such model of the State powers functions that would guarantee a good State government and would suit Lithuania today. Lithuania has chosen the parliamentary way. So, it would be interesting to know in what ways it is possible in the background of the parliamentary democracy to separate the competences of powers that the State authorities would not confront and would properly protect electors' interests.

By a long way it is more plausible that it is possible to use constructively the Presidential institution by strengthening the efficiency of the performance of the Parliament. Naturally, in the Parliamentary Republic the President is the first to be allocated with the role of moral authority of the State. In this respect he should act as the conciliator of different and even competing political forces, manifesting in the Parliament and in the society. However, when speaking about morality of the political powers, its most important indication pertains to how well the political powers serve the interests of the society and the State. Thus, moral authority of the President directly depends not upon his or her capability to reconcile the political fractions of the Parliament, but on whether these fractions do not lose a touch with their electors and live up to their expectations. In other words, the President must still possess certain political and legal authority to influence the Parliament to act in such a way that would be politically workable as well as politically responsible.

On the other hand, it is worthwhile not to forget here that in the State some functions exist that, under certain conditions from political and legal standpoint, can be consistently entrusted to the head of the State - the President. Regardless of their political choice, all citizens are equally interested in the public sobriety and national security. Despite of the variety of political interests in the society, the State must ensure social integrity and in particular in times when the public turmoil or external intervention looms. Such area of purely national objectives of the State was discerned 
by Romeris: "However, we are aware that the area of specific social objectives of the state is very narrow; these are the social order and peace and external defence (police in a broad sense including civil and criminal court as well as armed defence of the territory)" (Romeris 1995: 252).

\section{Constitutionality protecting function in presidential institution according to the Constitutions of France and Germany}

The first paragraph of article 5 of Section II of the French Constitution states: "The President of the Republic shall see that the Constitution is observed. He shall ensure, by his arbitration, the proper functioning of the public authorities and the continuity of the State". According to Philippe Ardant, these functions of the President, i.e. the right to dissolve the Parliament (art. 12) or the so-called right to "impose the dictatorship for the rescuing of society" (art. 16) is solely the prerogative of the President; however, they do not grant the empowerments to govern the State (Ардан 1994: 63-64).

Probably it is possible to agree with Ardant that these are not the empowerments to govern the State that would grant to the President the right to take over the legislation and other functions of the Parliament. The President of France under the veil of the society saviour may not impose one-man government to unilaterally pass the laws as well as implement them. However, it is noteworthy that in the times of the Parliamentary crisis or social confusion the President is procedurally empowered to act as a representative of the whole society. The President, as a reserved political figure, starts acting when other authorities objectively cannot continue performing their functions in a regular manner.

German specialists of constitutional law profess a somewhat similar attitude to the competence of the Presidential authority in the parliamentary system in their country. Johann Schleich maintains that in the Constitution of Germany three functions of the President are stipulated, such as integration, political reserve and legal reserve (Шлейх 1994: 231). When performing the function of integration, the Federal President embodies the political unity of the society, but this does not imply that the President creates this unity in accordance with the model planned by him. Schleich emphasized: "However, the integrating function of the Federal President does not mean that he acts from certain, especially high, spheres. The main law does not incorporate any express instruction, which would imply that the Federal Government represents the majority, and the Federal President - the entire nation" (Шлейх 1994: 232). This is a role of a mediator but not of the arbiter. The President does not make any decisions but only aids when searching for a compromise (Шлейх 1994: 232). Schleich pays attention to the fact that in the Constitution of Germany there is no term denominating the head of the State. To his opinion, "The lack of the political power in the President's disposition is the basis of his force which manifests in spiritual impact on the public policy. The Federal President impersonates things which are common to everybody. Simultaneously, he epitomizes the spirit of the Constitution" (Шлейх 1994: 232). Namely, that is his integrating function. 
The function of the political reserve, according to Schleich, is reserved for the President of Germany for the periods of crisis. The judge of the German constitutional law ascribes the following possibilities for the performance of this function: proposition of the Federal chancellor (apparently not necessarily the one that is acceptable to parliamentary majority - note of the author); dissolution of the Bundestag; announcement of the necessity to pass the law (Шлейх 1994: 238). The same author, basing upon provision of the first paragraph of article 82 of the Constitution of Germany which commits the President to prepare the laws for promulgation, states that "upon emergence of the constitution the President has the possibilities to undertake measures against violations of the constitutional system. Like a reserve player, he can join when there are no other ways left to overcome anti-constitutional actions of other authorities" (Шлейх 1994: 232). The President of Germany performs the legal reserve function by preparing laws, appointing ministers and high officials of the State.

\section{"Semi-Presidential" model as a nominal form of the State government of Lithuania}

When one speaks about the form of government of the State of Lithuania and the legal status of the President of the Republic of Lithuania within it, initially he would like to quote the thoughts of one of the most outstanding Lithuanian specialists of the constitutional law Egidijus Kūris: " $<\ldots>$ The Constitution of the Republic of Lithuania achieved a good deal - compromise formulations, which allow attributing the form of the state of Lithuania neither to strictly Presidential nor purely Parliamentary type, have been found. Although in this case there were obvious inconsistencies with "semiPresidential" model of France, this particular title was accepted the best when describing the governance approach of Lithuania" (Kūris 1998: 41). Many other Lithuanian specialists of politics and law sciences also define the governing of Lithuania as “semi-Presidential”.

\section{Lithuania as a Parliamentary Republic}

How this "semi-Presidential" model of governing is operating in reality? The problem of establishing legal status of the President in practical terms became very acute in 1998 after routine elections of the President of the Republic of Lithuania. In its resolution of 10 January 1998, the Constitutional Court of the Republic of Lithuania first of all stated that "in line with the competence of state institutions stipulated in the Constitution of the Republic of Lithuania, the governing model of Lithuania is attributable to Parliamentary Republic governing form” (The Official Gazette 1998). Furthermore, the Constitutional Court added, "some of the peculiarities of the socalled mixed (semi-Presidential) form of governing were inherent to the governing form of Lithuania”. In response to the claim submitted by the Government, the Constitutional Court determined that pursuant to the Constitution of the Republic of Lithuania the Government must "return the powers, by expressing their respect to the institution of the head of the state", but such a return of powers does not imply 
resignation. The Constitutional Court emphasized that the newly elected President of the Republic of Lithuania is obliged to submit the candidacy of until-then Prime Minister to Seimas for repeated approval for the post of Premier. This, according to the Constitutional Court, "is not just a manifestation of inter-institutional courtesy". Thus, the President of the Republic of Lithuania can verify, "whether Seimas continues to trust the Government". Consequently, it follows from the arguments set forth by the Constitutional Court that given the form of governance of Lithuania and political powers of the President, the Government which had earned the Seimas trust before the elections may continue the implementation of the program approved by Seimas. It may proceed until the end of term stipulated by Seimas, provided that Seimas approves their trust in premier proposed by the President. Based upon explanation of the Constitutional Court, there are no possibilities for the President to form a Government of his trust and act as a head of Presidential government. Therefore, Lithuania is a Parliamentary Republic.

\section{The problem of President's powers and the definition of His or Her constitutional status in Lithuania}

Consequently, in order to find out what is the legal status of the President of the Republic of Lithuania in the constitutional system of powers' division, it is essential to expressly define the legal possibilities for the President to influence the activities of the Parliament and the Government "in the framework of parliamentary form of state governance in conjunction with certain peculiarities of semi-Presidential form". The Constitutional Court expressed their opinion about such legal possibilities of the President in the above-mentioned resolution as well. The first element of the legal status of the President, which could be listed based on the resolution of the Constitutional Court, pertains to the fact that the President of the Republic of Lithuania as the head of the State, who is elected in direct elections, has his "program objectives". In other words, the Constitutional Court admitted that the body of electors when electing the President of the Republic simultaneously vote for his program objectives, which the President is obligated to implement later on when performing the due functions. Furthermore, the Constitutional Court listed some of the constitutional procedural forms for the implementation of program objectives of the President: a) to submit appropriate draft projects of laws; b) to recommit the laws passed by Seimas (right of veto); c) to appeal to the Constitutional Court regarding the compliance of deeds of the Government to the Constitution and the legislation; d) to announce notifications about the situation in Lithuania, internal or foreign policy.

Another element of special significance of the legal status of the President established by the Constitutional Court should pertain to the fact that basing on the constitutional model of the State powers' division provided for in the Constitution (article 5), the President is "a part of the executive branch". However, the Constitutional Court did not equate the Presidential authorizations to the President of the Presidential Republic. Instead, the Constitutional Court remarked that "the President is the head of the state, he represents the state and fulfils all that is committed to him by the 
Constitution and the legislation, and the Government is the executive managing institution of the State".

After an in-depth analysis of the discussed legal means for the President of the Republic of Lithuania to make political impact on operations of the Government and the Parliament, it can be noted that a possibility for a conflict of state powers exists in the form of governing of the State of Lithuania which is defined as "Parliamentary form with some peculiarities of semi-Presidential form”. Indeed, during the direct elections to Seimas the electorate grants to the Parliamentary majority the right to form the Government and to implement the Government program, supported by the majority of Parliament. The directly elected President of the Republic of Lithuania is, in turn, granted by the electorate the authority to pursue his "program objectives". He can realize those through the above-mentioned procedures, which are stipulated in the Constitution. However, the Constitution does not state which program, that of the President or the parliamentary majority, has a superior legal status. Therefore, initially formally, de jure, it is likely that a situation will occur where individual provisions of the Government program of the parliamentary majority and those of the program of the President (direct obligations to the electors) may differ or even conflict. Consequently, this implies that there is a possibility for a conflict of the State powers between the President and the majority of Parliament in conjunction with the Government supported by them, programmed in the Constitution of the Republic of Lithuania, when these two powers interpret their obligations to the electors differently. Of course, such conflict would be hardly plausible if the Presidential elections would have been won by the candidate who was supported by the ruling political majority and who, inter alia, would be declaring in his electoral program objectives the same or similar ideas to those of the ruling majority of the Parliament. In contrary, it may happen that the Presidential elections will be won by the candidate who is supported by the party, opposing to the ruling majority of the Parliament or even by a non-party candidate. Particularly in that case the possibility of disagreement or conflict of the State powers becomes likely indeed.

\section{"The divided power" of the State's authorities and the subjective nature of assurance of solidarity of the State's authorities in Lithuania}

When speaking about the possibility for a conflict of the State powers programmed in a constitutional level, one can appeal to the insights and conclusions of the judges of constitutional law. Giovanni Sartori, a famous Italian political scientist, renowned in the world for his election systems and theories of democracy, when assessing the operation of interaction of the American constitutional powers, in his book Comparative Constitutional Engineering: An Inquiry into Structures, Incentives and Outcomes singled out the following two concepts: the first: "division and separation of powers"; and the second: "the divided power" (Sartory 2001: 96-98). The first notion conveys such interaction of the American powers where the Congress and the President while representing two different powers, do not conflict among themselves and pursue "the united policy". According to Sartori, such situation usually occurs in cases when "the 
same majority controls the executive branch as well as the Congress" in the American constitutional practice". "Such were the theory as well as practice of the governing of America for a century and a half” (Sartory 2001: 97). Simultaneously Sartori notes that there are periods in the American practice, when the conflicting "model of the divided power" prevails. In 1954 as well as in 1957 Dwight D. Eisenhower was the first President over the period of seventy two years who had to deal with the Congress controlled by the opposition party". Later on "from 1955 to 1992 the governing has been divided for twenty six years out of thirty eight" and "over the period from 1969 to 1992 the governing was divided for twenty years out of twenty four” (Sartory 2001: 97). Such structure of the "divided power" in particular, as Sartori noted, is iniquitous due to the reason that "it reveals in front of our eyes the broken-up and contrasting political community, where every of the two most important components interpret their own electoral interest in general as a failure of the other institution. To support a Republican President for the Congress controlled by the democrats equals to cry for another cadence of the Republican. And vice-versa, the president who has the minority (in Congress) and is seeking to re-enact the undivided governing, cannot do without throwing accusations at the Congress" (Sartory 2001: 98).

To go back to the assessment of the relationships between Lithuanian powers, it can be stated that the conflicting relationships between the President and the parliamentary majority could be characterized precisely as the situation of "divided powers". The possibility for such an assessment is confirmed by actual examples, when the president and parliamentary majority represent different political forces. For instance, Valdas Adamkus, who won the presidential elections in 1997 has large ambitions to pursue his electoral promises. Being unable to constitute his government (as mentioned, such a possibility was eliminated by the resolution of the Constitutional Court which stated that Lithuania was a Parliamentary Republic with features characteristic to the semi-Presidential Republic), the President Adamkus recounted his electoral program in the beginning of 1999, when making an annual report in Seimas on the situation in Lithuania, internal and foreign policy of the Republic of Lithuania, as stipulated in Section 18 of article 84 of the Constitution. In His annual report, the President declared that "He will be representing the interests of all citizens and not those of separate political parties or economic groups”. Furthermore, He admitted that despite His "extremely high moral and political responsibility, laid upon by the Constitution, the President as the head of the state has "only limited authority to live up to this responsibility”. By reference to His limited political possibilities, in particular the President Adamkus in delicate form invited the members of Seimas "to openly exchange different opinions, discuss" and "after finding the solutions, to implement them fairly for the welfare of people and for the good of the State”. Further events demonstrated that electoral objectives of the President, set forth in the annual report, have not become an integral part of the Government program. Confrontation, but not a dialogue, took place between the Government supported by the majority of the Seimas and the President Adamkus, which ended in the President Adamkus' public 
motion of non-confidence in spring of 2000 against the head of the Government Gediminas Vagnorius, who resigned following this motion of the President.

The situation of the "divided power" arose in Lithuania after the next presidential elections as well. Rolandas Paksas, who became the President of the Republic of Lithuania at the end of 2002, also had an ambitious political program and the resolution to pursue it. Under the headship of the President Paksas regular meetings of the President and the members of the Government, where the President used to express his attitude to the operations of the Ministries and the requests became a norm. The legal basis for such meetings was the second part of article 96 of the Constitution, which stipulates that "while presiding over the assigned areas of governing, the ministers are accountable to Seimas, the President of the Republic of Lithuania and directly under the control of the Prime Minister". Not long afterwards, in autumn 2003, an impeachment process was initiated against the President Paksas, which ended with Paksas' removal from the office.

As it can be seen, Constitutions of France and Germany provide for the President's integrating function as well as the political reserve function. When having the possibility to join the political process only as a reserve figure, the President cannot hinder the work of the parliamentary government. Thus, the "divided power" situation is prevented and the unity of the policy pursued by the authorities is ensured. The possibility for the President of France to regularly supervise the Parliament and the Government of the parliamentary majority is worth of a separate notice. It is the right to dissolve the Parliament, when the President deems advisable. It could be considered as a political measure unrepresentative of parliamentary form. However, when anticipating or taking into account the condition that having dissolved the Lower House the President does not obtain the right to constitute His own government but must commence premature elections and entrust the executive branch to the newly elected majority of the Parliament, it can be stated that the President's right to dissolve the Parliament is a constitutional means, available to Him to ensure politically responsible to the electors activities of the entire Parliament and the government of parliamentary majority. In this respect, the idea of the famous French specialist of last century of constitutional law Adhémar Esmein looks easily understandable: "the Parliament dissolution right is the key and almost core feature of parliamentary governance" (Esmein 1932: 263).

\section{Constitutional possibilities to improve the parliamentary efficiency system in Lithuania}

When speaking about the possibilities for the President of the Republic of Lithuania to perform the functions of protecting constitutionality and the political and legal reserve, it can be stated that these possibilities are very limited and barely nominal. The President may not dissolve the Seimas not only when He or She is confident that Seimas has lost the trust of electorate (e.g. as in France) but even in cases when there are difficulties in the constitution of the political majority which forms the Government and when this majority does not form altogether for an indefinite period of time. In 
such case the President would be forced to live with formation of the Government of Seimas' minority. Furthermore, the President of the Republic of Lithuania is not entitled to appeal to the Constitutional Court regarding verification of constitutionality of individual acts passed by Seimas. Apparently, without authorizations to perform the functions of the political and legal reserve (e.g., the right to dissolve Seimas in cases where the latter due to its imprudence loses the trust of electors), the President can perform His integrating function also in a limited way. Every member of the Seimas is aware that his cadence lasts for four years regardless of his performance. This circumstance inevitably conditions the fact that every member of the Seimas tends to demonstrate his oneness or, conversely, passiveness. It becomes more complicated for the members of the Seimas to search for compromises and to make collegial decisions in general.

\section{References}

Esmein, A. 1932. Konstitucinès teisès principai. Kaunas: Teisininkų draugija.

Kūris, E. 1998. „Politinių klausimų jurisprudencija ir Konstitucinio Teismo obiter dicta: Lietuvos Respublikos Prezidento institucija pagal Konstitucinio teismo 1998 m. sausio 10 d. nutarimą“, Politologija 1(11): 27-74.

Romeris, M. 1995. Suverenitetas. Vilnius: Pradai.

Sartori, G. 2001. Lyginamoji konstitucinė inžinerija. Vilnius: Pradai.

„Valstybès žinios“. 1998. Nr. 5-99.

Ардан, П. 1994. Франция: государственная система. Москва: Юридическая литература.

Шлейх, И. 1994. Федеральный президент: Государственное право Германии. Москва: Юридическая литература. 


\title{
TAUTOS SUVERENITETAS PARLAMENTINĖJE LIETUVOS SISTEMOJE: PROBLEMOS IR PASIŪLYMAI
}

\author{
Saulius Arlauskas
}

\begin{abstract}
Santrauka
Straipsnyje siekiama parodyti, kaip parlamentinè valdymo forma gali užtikrinti deramą žmonių interesų atstovavimą. Remiantis Mykolo Romerio idèjomis apie suvereno ir valdžios santyki teigiama, kad parlamentinès valstybès Konstitucijoje privalo būti numatyta speciali konstitucingumo apsaugos funkcija kaip suvereno valios išraiška. Parodoma, kad tokia funkcija numatyta Prancūzijos ir Vokietijos Konstitucijose, suteikiant Prezidentui funkciją užtikrinti deramą parlamentinès sistemos veikimą (politinio ir teisinio rezervo funkcija). Atskleidžiama, kad Lietuvoje, kuri taip pat yra laikoma parlamentine respublika, Prezidentas politinio ir teisinio rezervo funkcijos neatlieka ir atitinkamų igaliojimų neturi. Straipsnyje siūloma pasekti Prancūzijos ar Vokietijos Konstitucijų pavyzdžiu ir peržiūrèti Seimo bei Prezidento kompetencijas.

Reikšminiai žodžiai: Konstitucija, Lietuva, suverenitetas, valstybės valdžios padalijimas.
\end{abstract}

Received 7 May 2010, accepted 10 June 2010 